\title{
Institutional Quality and Tourism Growth Nexus in MENA Countries
}

\author{
Isah Wada ${ }^{1}$
}

\begin{abstract}
The study critically examines the impact of institutional quality within foreign direct investment-financial development-international tourist arrival nexus for selected MENA countries. The dynamic pool mean group Autoregressive Distributed Lag (ARDL) model is employed for the empirical data analysis from 2012 to 2018. The findings reveal that institutional quality has a positive impact in FDI and real GDP model. Contrarily, it has adverse effect in the model of financial development and international tourist arrival overtime. Hence in the short-run, financial development and real GDP vary inversely moreover international tourist arrival and financial development varies directly. The multivariate panel causality test reveals 4 significant uni-directional causalities. The robust finding suggests institutional policy measures to enhance FDI and international tourist arrival, and the deepening of financial development to stimulate and enhance economic growth.
\end{abstract}

Keywords: Autoregressive Distributed Lag (ARDL), economic growth. international tourist arrival, institutional quality, $M E N A$ countries

JEL classification: $C 5, Q 4, Z 3, Z 0$

DOI: $10.24818 / \mathrm{REJ} / 2021 / 81 / 01$

\section{Introduction}

The quality of institutions regarding democratic accountability, political stabilization, governmental effectiveness, regulatory framework, anti-corruption, and rule base system are credible factors for the economy. Moreover, evidence suggests that credible institutional quality is vital in promoting foreign direct investment (FDI) welfare gain (Acemoglu and Johnson, 2005; Benassy Quere et al., 2007; Buchanan et al, 2012) and enhancing tourism development. Thus, FDI inflow to the country with excellent institutional governance quality can more broadly and easily enhanced tourist arrival. Additionally, poor institutional governance structure significantly diminishes FDI inflow (Wei, 2000; Li and Resnikk, 2003; Belgibayeva and Plekhanov, 2015; Dauda and Stein, 2007) and

\footnotetext{
${ }^{1}$ Department of Accounting and Finance, Institute of Social Sciences University of Mediterranean Karpasia, Northern Cyprus via Mersin-10, Turkey; Nisantasi University, Faculty of Economics, Administrative and Social Sciences Department of Economics, Istanbul Turkey, e-mail: isah.wada@akun.edu.tr
}

Year XXIV no. 81

September 2021 
impedes tourism growth, more generally. Therefore the overall institutional quality in terms of good governance, democratic accountability, political stability, and awareness help significantly promotes rapid tourism attraction. Thus, in burgeoning studies, FDI is arguably potent in accelerating tourism potential for recipient countries. The potential linkages of FDI, financial development, and tourism growth within the causal nexus of institutional quality are yet unexplored-adequately, in the extant literature. Accordingly, the question whether FDI, financial development and robust institutional quality in recipient country give impetus for tourism potential, boosting real growth is explored. The reference countries of interest for the investigation are selected economies from the Middle East and North African region (MENA)—notably, Algeria; Egypt; Iran; Jordan; Kuwait; Lebanon; Sudan and Tunisia. Known for its high diversity, the MENA region has undergone various transformation with potential capacity for sustainable growth. Comparatively, the region possess huge advantage in various sector namely, renewables, tourism, manufacturing and financial services. Hence, there has been appreciable efforts at enhancing FDI inflows into the region. In recent times, strengthening institutional reforms and diminishing stifling regulatory framework have been the main focus.

In theory, the spill over impact of FDI is enhanced by technical penetration of innovation, financial development, the soundness of institutional quality and overall economic environment (Chamarbagwala et al, 2000; Alfaro et al. 2004). The current study seeks to close this gap in literature while investigating the following questions. Is there dynamic nexus between FDI, financial development, Institutional quality, and tourism potentials? And does institutional quality matter in the dynamic relationship of FDI, financial development, and tourism potential. And what is there dynamic causal nexus? The study bridge the gap in the literature by exploring the dynamic causal nexus of FDI, financial development, institutional quality, tourism potential, and economic growth. It adopts the empirically robust Pesaran, Shin, and Smith (PSS, 1999) pooled mean group (PMG) econometric technique yielding superior estimates. Hence, estimating the dynamic linkages of the model variables, the study has the added advantage of estimating the causality of the variables in a multivariate sense.

\section{Research Method}

The PSS (1999) panel ARDL modifies the standard ARDL to a panel estimation framework incorporating respective cross-sectional intercepts, short-run dynamic coefficients, and cointegration terms. This method is applicable even with mixed integration order circumventing the estimation drawbacks associated with standard ARDL - due to the inherent correlation of the mean-differenced regressors and the stochastic specification.

Year XXIV no. 81

September 2021 
The PMG ARDL model is specified as follows;

$\Delta q_{i t}=\delta_{i} E c_{i t}+\sum_{k=0}^{s-1} \Delta X_{i, t-k} \alpha_{i_{s} k}+\sum_{k=1}^{v-1} \beta_{i_{s} k} \Delta q_{i_{s} t-k}+\varepsilon_{i, t}$

Where $E c_{i, t}=q_{i, t-1} \quad X_{i, t} \vartheta^{9}$ is the equilibrium correction error term, associated with $\vartheta$, the long-run coefficients and $\delta_{i}$ is the dynamic adjusting coefficients.

To empirically answer the research question posed, the following models are estimated ;

$$
\ln F D I_{t}=\beta_{0}+\beta_{1} \ln F D I_{i t-1}+\beta_{2} \ln F D_{i t}+\beta_{3} \ln I T A_{i t}+\beta_{4} I S Q_{i t}+\beta_{5} \ln G D P_{i t}+\varepsilon_{i t 1}
$$

$\ln F D_{t}=\gamma_{0}+\gamma_{1} \ln F D_{i t-1}+\gamma_{2} \ln I T A_{i t}+\gamma_{3} \ln G D P_{i t}+\gamma_{4} I S Q_{i t}+\gamma_{5} \ln F D I_{i t}+\varepsilon_{i t 2}$

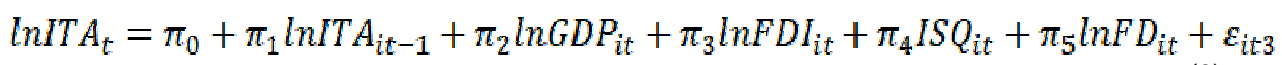

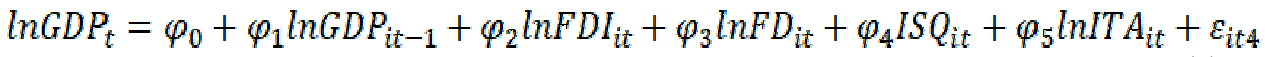

Except for the institutional quality variable - a categorical data, the remaining variables are in their natural logarithm. The constant terms are the following; $\beta_{0}$, $\gamma_{0}, \pi_{0}$, and $\varphi_{0}$. The stochastic white noise terms are $\varepsilon_{i t 1}, \varepsilon_{i t 2}, \varepsilon_{i t 3}$, and $\varepsilon_{i t 4}$. In the specified equations, the ' $i$ ' subscript gives the series ith term, where $i=1$.........8) and the time dimension is represented by ' $t$ ', where $t=2002-2018$. The study adopts six components in modeling institution quality, namely; 'accountability, political stability, government effectiveness, regulatory quality, control of corruption, rule of law' (see Kaufman et al. 2010). These indicators are aggregated based on a huge data source from global survey and assessment on governance perception. The indicator on governance approximately range from -2.5 for weak performance to +2.5 for strong performance. The estimates are derived from the World Wide Governance Indicator (WGI) database. To obtain the institutional quality variable, the principal component analysis (PCA) is applied in aggregating the aforementioned indicators. 
The remainder of the data employed are FDI, financial development (FD), international tourist arrival (ITA), and real gross domestic product (GDP) obtained from the World Bank Development Indicator (WDI). FDI is the net inflow of investment capital comprising of equity and earning reinvestments in United States Dollar (USD). FD is proxied with domestic credit to the private sector (percentage of GDP_\%GDP). It includes the financial capital of business corporations and to a limited extent financial credit to public sector enterprises. To model tourism development, the international tourist arrival (ITA) data is employed. ITA means inbound international tourist arrival within 12 months to countries outside their domestic residency. GDP is the real gross domestic product in 2010 constant USD.

As part of the estimated coefficient diagnostic examination, the $95 \%$ confidence ellipse plot reveals that the regressors are not serially correlated and highly robust. This is revealed by the full circular shape of the plots.

Figure 1 The diagnostic confidence ellipse coefficient test

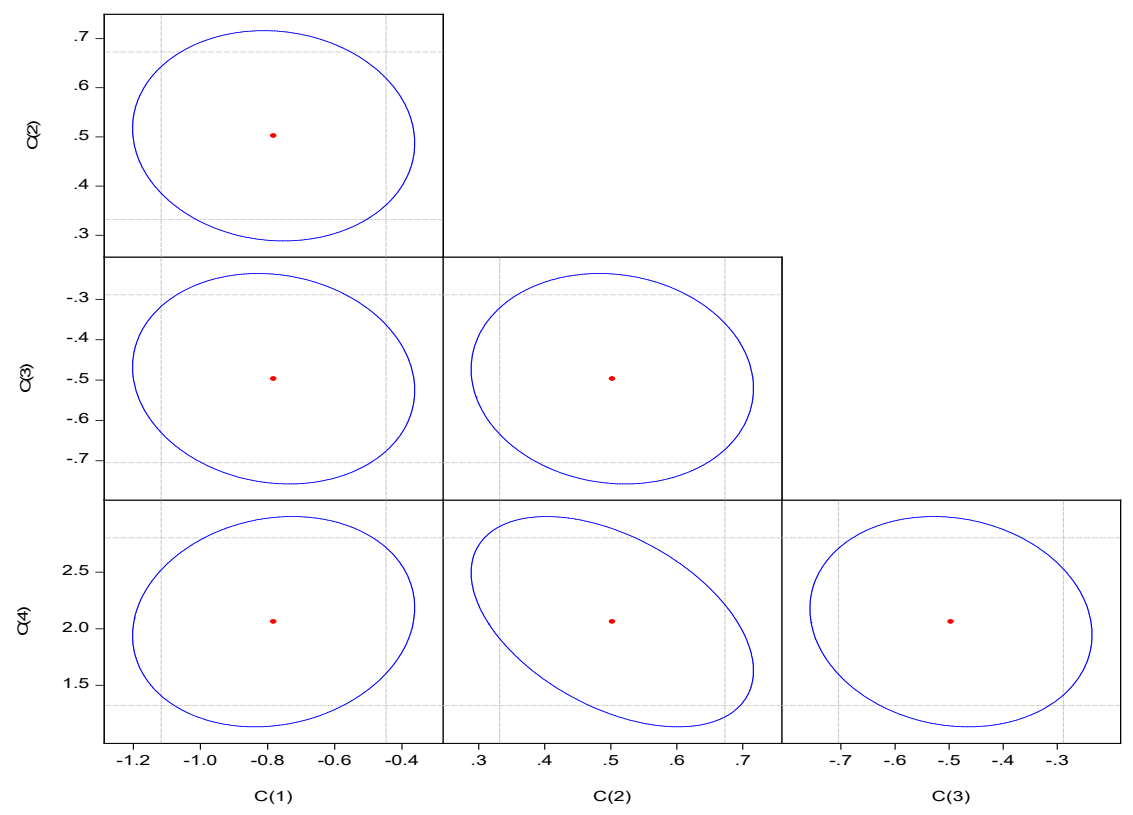

\section{Empirical result discussion}

Table 1 presents the estimates of equation (1) to (4). In model 1 financial development and institutional quality have a statistically significant positive 
relationship with FDI in the long-run $\left(\beta_{2}=0.78214, \mathrm{p}<0.01\right.$ and $\beta_{4}=0.4967, \mathrm{p}<0.01$ ). Thus, in the long term, a $1 \%$ expansion in financial development and institutional quality causes FDI to increase by about $0.78 \%$ and 0.50\%. The finding confirm Bénassy-Quéré et al., (2007); Daude and Stein, (2007) results where quality institutional governance is critical for FDI inflow. Thus the result shows that the lack of a robust financial system and good institutions diminishes FDI inflow (Choong et al., 2004). Also, the international tourist arrival and output growth have a statistically significant positive relationship with FDI overtime $\left(\beta_{3}=0.5023, \mathrm{p}<0.01\right.$ and $\left.\beta_{5}=2.0622, \mathrm{p}<0.01\right)$. Therefore a $1 \%$ increase in international tourist arrival and output growth increases FDI by around $0.50 \%$ and $2.06 \%$ in the long-run. The result upholds the output growth-FDI inflow bi-directional nexus (Hermes and Lensink, 2003) and confirm the positive relationship between international tourist arrival and FDI (Fauzel, 2020).

Table 1 - The PSS (1999) panel ARDL Estimates

\begin{tabular}{l}
\hline \\
LNFDI
\end{tabular}

Year XXIV no. 81

September 2021 


\begin{tabular}{|c|c|c|c|c|c|c|c|c|}
\hline 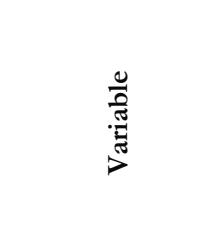 & $\frac{\bar{J}}{\frac{J}{0}}$ & 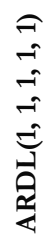 & 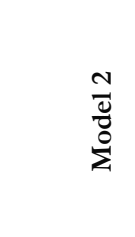 & $\begin{array}{l}\approx \\
\therefore\end{array}$ & $\begin{array}{l}n \\
\frac{0}{0} \\
\sum_{i}^{0}\end{array}$ & 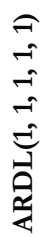 & $\frac{\nabla}{\frac{J}{\delta}}$ & 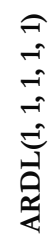 \\
\hline Schwarz criterion & 3.918744 & & 0.530732 & & -0.426772 & & -3.536387 & \\
\hline $\begin{array}{l}\text { Hannan-Quinn } \\
\text { criteria. }\end{array}$ & 3.155939 & & -0.130366 & & -1.087870 & & -4.197485 & \\
\hline Log-likelihood & -119.0950 & & 91.63926 & & 156.7495 & & 368.2033 & \\
\hline
\end{tabular}

Note: ${ }^{* * *},{ }^{* *}$, and $*$ indicate significant at $1 \%, 5 \%$ and $10 \%$ respectively

The short-run relationship in model 1 yeild estimates that are statistically insignificant. But, the equilibrium adjustment term is as expected, negative and significant $\left(F c_{t}=-1.036118, \mathrm{p}<0.01\right)$. This give dampen and sluggish adjustment of the model to its long-run equilibrium.

In model 2, we found a inverse statistically significant relationship between institutional governance quality and financial development in the long-run $\left(\gamma_{4}=-0206198, p<0.01\right)$. Hence, increasing overall institutional quality governance by $1 \%$, financial development contracts by about $0.21 \%$. Hence, institutional governance measure that creates bottle-neck increases cost of doing business (Wei, 2000) and yield adverse impact (see Belgibayeva and Plekhanov, 2015; Li and Resnick, 2003).

In the short-run for model 2 , international tourist arrival estimate and financial development move oppositely $\left(\gamma_{2}=-0.709050\right)$. Hence a $1 \%$ increase in international tourist arrival results in about $0.72 \%$ decrease in financial development. Meaning that uncertainity of international tourist arrival reduces financial flow and possible financial development slowdown (see Seetanah et al. 2019). Although Başarir and Çakir (2015) found a bi-directional relationship for tourism-financial development nexus in the long-run. Song and Lin (2010) study shows that uncertain financial conditions can lead to negative relationship between international tourist arrival and financial development. The adjustment coefficient is found to be negatively significant $\left(E c_{t}=-0.385104, \mathrm{p}<0.01\right)$ in model 2 and the model adjusts by about 39\% every period to reach equilibrium.

The estimates of model 3 shows that real output growth, FDI, and financial development have a statistically significant positive relationship with international tourist arrival in long-run 
$\left(\pi_{2}=0.271202, \mathrm{p}<0.01 ; \pi_{3}=0.035218, p<0.01\right.$

and

$\pi_{5}=0.271202, \mathrm{p}<0.01$. The results aligned with evidence of postive economic growth-tourism nexus (see Payne and Mervar, 2010) and bi-direction responses amongst tourism output growth, FDI, and financial development nexus (see Shahbaz et al. 2016). Therefore a 1\% increase in real output growth, FDI, and financial development means international tourist arrival rises by about $0.27 \%$; $0.035 \%$, and $0.27 \%$ correspondingly.

In contrast, institutional quality is found to have an opposite relationship with international tourist arrival $\left(\pi_{4}=-0.190937 \mathrm{p}<0.05\right.$ ) (see also Wei, 2000). Therefore, $1 \%$ increase in institutional quality decreases international tourist arrival by $0.19 \%$ in the long-run. The finding justifies Wei (2000) that adverse/stringent institutional policy discourages foreign investors and international tourists.

Although the short-run estimates are not individually statistically significant, the equilibrium adjustment term is significantly negative $\left(F c_{t}=-0.349786, \mathrm{p}<0.01\right)$ indicating an adjustment speed of $35 \%$ annually to long-run.

Lastly, model 4 evidenced significant direct relationship for the regressors and real output growth in the long-run $\varphi_{2}=0.216965, \mathrm{p}<0.01 ; \varphi_{3}=0.746193, \mathrm{p}<0.01 ; \varphi_{4}=0.310216, \mathrm{p}<0.01$ and $\varphi_{5}=$ $(0.293604$

$\mathrm{p}<0.01$ ). Accordingly, a $1 \%$ expansion in FDI, financial development, institutional quality, and international tourist arrival increases real output growth by $0.22 \% ; 0.75 \% ; 0.31 \%$, and $0.29 \%$. This validates De Mello (1999); Lipsey, 2002; Javorcik, 2004 and Alfaro et al. (2004) FDI-GDP growth positive relationship assertion. And the notion that a robust financial system is essential for FDI inflow and economic growth (see Hermes and Lensink (2003) financial, Alfaro et al., 2004; Durham, 2004). In short-run, financial development and real output growth are inveresely related $\left(\varphi_{3}=-0.039459, \mathrm{p}<0.01\right)$. A $1 \%$ growth in financial development reduces real output by $0.04 \%$. Demetriades and Hussein, (1996) also found little support for financial development lead growth in their study. Also, the dynamic adjustment coefficient is negative and significant $\left(E c_{t}=-0.040987, \mathrm{p}<0.01\right.$ ), and the estimated model adjusts to its long-run equilibrium slowly, about $4 \%$ annually.

Thus, using the 6 categories of the institutional variable indicators reported by WGI, we found that institutional quality plays a positive role for real outgrowth 
overtime and foreign direct investment. Conversely, it has adverse implication for financial development, and international tourist arrival. The result empirically suggests that too much institutional regulation can stifle long-run financial development and international tourist arrival.

Table 2. Pairwise Dumitrescu Hurlin Panel Causality Tests

\begin{tabular}{|c|c|c|c|}
\hline Null Hypothesis: & W-Stat. & Zbar-Stat. & Prob. \\
\hline$\overline{\text { LNDC does not homogeneously cause LNFDI }}$ & 1.42139 & -0.94525 & 0.3445 \\
\hline LNFDI does not homogeneously cause LNDC & 2.90926 & 0.35866 & 0.7198 \\
\hline LNITA does not homogeneously cause LNFDI & 4.24994 & 1.53357 & 0.1251 \\
\hline LNFDI does not homogeneously cause LNITA & 2.71776 & 0.19084 & 0.8487 \\
\hline ISQ does not homogeneously cause LNFDI & 1.66013 & -0.73603 & 0.4617 \\
\hline LNFDI does not homogeneously cause ISQ & 1.83255 & -0.58492 & 0.5586 \\
\hline LNGDP does not homogeneously cause LNFDI & 2.49840 & -0.00140 & 0.9989 \\
\hline LNFDI does not homogeneously cause LNGDP & 5.07661 & 2.25802 & 0.0239 \\
\hline LNITA does not homogeneously cause LNDC & 5.87692 & 2.95939 & 0.0031 \\
\hline LNDC does not homogeneously cause LNITA & 3.86640 & 1.19745 & 0.2311 \\
\hline ISQ does not homogeneously cause LNDC & 3.75195 & 1.09716 & 0.2726 \\
\hline LNDC does not homogeneously cause ISQ & 3.34533 & 0.74081 & 0.4588 \\
\hline LNGDP does not homogeneously cause LNDC & 4.26179 & 1.54395 & 0.1226 \\
\hline LNDC does not homogeneously cause LNGDP & 1.71646 & -0.68666 & 0.4923 \\
\hline ISQ does not homogeneously cause LNITA & 9.05230 & 5.74215 & 9.E-09 \\
\hline LNITA does not homogeneously cause ISQ & 2.75553 & 0.22393 & 0.8228 \\
\hline LNGDP does not homogeneously cause LNITA & 2.70099 & 0.17614 & 0.8602 \\
\hline LNITA does not homogeneously cause LNGDP & 2.96910 & 0.41110 & 0.6810 \\
\hline LNGDP does not homogeneously cause ISQ & 5.19193 & 2.35909 & 0.0183 \\
\hline
\end{tabular}

Year XXIV no. 81

September 2021 
10

The Romanian Economic Journal

\begin{tabular}{cccc}
\hline Null Hypothesis: & W-Stat. & Zbar-Stat. & Prob. \\
& & & \\
\hline ISQ does not homogeneously cause LNGDP & 3.51021 & 0.88531 & 0.3760 \\
\hline
\end{tabular}

\subsection{Panel Granger Causality}

In general, the panel Granger causality test is undertaken within bivariate setting of the following form;

$$
\begin{aligned}
& q_{i t}=\beta_{0 i}+\beta_{1 i} q_{i, t-1}+\cdots+\beta_{k i} q_{i, t-k}+\gamma_{1, i} g_{i, t-1}+\cdots+\gamma_{k, i} g_{i, t-k}+\varepsilon_{i t} \\
& g_{i t}=\beta_{0 . i}+\beta_{i .} g_{i . t-1}+\cdots+\beta_{k . i .} g_{i, t-k}+\gamma_{1, i} q_{i, t-1}+\cdots+\gamma_{k, i} g_{i, t-k}+\varepsilon_{i t .}
\end{aligned}
$$

Where the panel time dimension is given by $\mathrm{t}$ and dimension of the cross-sections is dennoted by i. Thus by following the approach of Dumitrescu-Hurlin (2012), the coefficient of the cross-sectional regression is allowed to differ across the sample such that;

$$
\begin{aligned}
& \beta_{0, i} \neq \beta_{o, j} \beta_{1, i} \neq \beta_{1, j} \ldots \beta_{1, i} \neq \beta_{1, j} \neq \beta_{1, i} ; \forall_{i, j} \\
& \gamma_{1, i} \neq \gamma_{i, j} \ldots \gamma_{1, i} \neq \gamma_{1, j} \forall_{i_{, j}}
\end{aligned}
$$

Hence by applying the standard cross-sectional causality regression, the test is performed based on the zbar statistic with a normal distribution.

The result of the causality test is shown in Table 4 and reveal 4 significant unidirectional causalities: From FDI to real output growth $(p<0.01)$; international tourist arrival to financial development $\left(p^{<}<0.01\right)$; institutional quality governance to international tourist arrival $(p<0.01)$ and real output growth to institutional quality ( $p<0.05$ ). In each of the aforementioned Granger causality, the historical past behavior of the respective variable can reliably suggest the future trajectory of the other variable in the equation. In the remaining cases examined, the null hypothesis cannot be rejected. Thus it is established that the institutional quality variable matter most in the model of international tourist arrival and real output growth. This is also evidenced in Buchanan et al. (2012). The evidence shows that as economies reach long-run economic growth and attract greater international tourists to the country, institutional quality receives greater attention.

Year XXIV no. 81

September 2021 


\section{Conclusion}

The novel panel ARDL estimation approach was adopted to examine the nexus of FDI, financial development, and tourism development for the MENA-8 countries from 2002 to 2018. The estimate of institutional quality in long-run exerts positive impact in the models of FDI; financial development; international tourist arrival; and real GDP. Hence, institutional quality directly impact long-run output growth.

In short-run, financial development and real output have inverse relationship; international tourist arrival and financial development varies indirectly; and institutional quality reduced international tourist arrival. The panel causality test confirmed one-way causality for 4 scenarios. Hence, institutional quality matters significantly in the models of international tourist arrival and real output growth.

Policymakers must vigorously pursue sustainable institutional quality policy to attract international tourist arrival while promoting FDI. And at the same time, deepen financial development to drive economic growth. Finally, the estimates of cross-country regression ${ }^{2}$ support country-specific policy initiative for effectiveness

\section{References}

Acemoglu, D., \& Johnson, S. (2005). Unbundling institutions. American Economic Review, 113(5), 949-995.

Alfaro, L., Areendam, C., Sebnem, K., \& Selin, S. (2004). FDI and economic growth: The role of local financial markets. Journal of International Economics, 64: 89-112.

Arellano, M., \& Bond, S. R. (1991). Some tests of specification for panel data: Monte Carlo evidence and an application to employment equations. Review of Economic Studies, 58, 277-297.

Başarir, C., \& Çakir, Y. N. (2015). Causal interactions between CO2 emissions, financial development, energy, and tourism. Asian Economic and Financial Review, 5(11), 1227-1238.

Belgibayeva, A., \& Plekhanov, A. (2015). Does corruption matter for sources of foreign direct investment? Working Paper No. 176, European Bank for Reconstruction and Development, London.

Bénassy-Quéré, A., Coupet, M. \& Mayer, T. (2007). Institutional determinants of foreign direct investment. The World Economy, Vol. 30 No. 5, pp. 764-782.

\footnotetext{
${ }^{2}$ The result of the short-run country-specific regression is available upon request. For brevity, the result has not been reported here to conserve space.
}

Year XXIV no. 81

September 2021 
Borensztein, E., Jose D. G., \& Jong-Wha, L. (1998). How does a foreign direct investment affect economic growth? Journal of International Economics, 45: 115-135.

Buchanan, B. G., Le, Q. V., \& Rishi, M. (2012). Foreign direct investment and institutional quality: Some empirical evidence. International Review of Financial Analysis, 21, 81-89.

Carkovic, M. V., \& Ross, L. (2005). Does foreign direct investment accelerate economic growth? in T. H. Moran, E. M. Graham \& M. Blomström, eds., Does Foreign Direct Investment Promote Development?, Washington, D.C., Institute for International Economics.

Chamarbagwala, R., Sunder R., \& Phanindra, V. W. (2000). The role of foreign capital in domestic manufacturing productivity: Empirical evidence from Asian economies. Applied Economics, 32: 393-398.

Chien-Chiang L., \& Chun-Ping, C. (2009). FDI, Financial Development, and Economic Growth: International Evidence. Journal of Applied Economics, 12:2, 249-271, DOI:10.1016/S1514-0326(09)60015-5

Choong, C., Zulkornain, Y., \& Siew-Ohoo, S. (2004). Foreign direct investment, economic growth, and financial sector development. ASEAN Economic Bulletin, 21: 278-289.

Daude, C., \& Stein, E. (2007). The quality of institutions and foreign direct investment. Economics and Politics, Vol. 19 No. 3, pp. 317-344.

De Mello, L. R. (1997). Foreign direct investment in developing countries and growth: A selective survey. Journal of Development Studies, 34: 1-34.

Demetriades, P. O., \& Hussein, K. A. (1996). Does financial development cause economic growth? Time-series evidence from 16 countries. Journal of Development Economics, 51(2), 387-411. doi:10.1016/s03043878(96)00421-x

Dumitrescu, E.-I., \& Hurlin, C. (2012). Testing for Granger non-causality in heterogeneous panels. Economic Modelling, 29(4), 1450-1460. doi:10.1016/j.econmod.2012.02.014

Edison, H. J., Levine., R, Ricci., L, \& Slok, T. (2002). International financial integration and economic growth. Journal of International Money and Finance, 21: 749-776.

Fauzel, S. (2020). FDI and tourism futures: a dynamic investigation for a panel of small island economies. Journal of Tourism Futures, Vol. ahead-of-print No. ahead-of-print. https://doi.org/10.1108/JTF-05-2018-0026

Hermes, N., \& Robert, L. (2003). Foreign direct investment, financial development, and economic growth. Journal of Development Studies, 40: 142-163. 
Hermes, N., \& Robert, L. (2003). Foreign direct investment, financial development, and economic growth. Journal of Development Studies, 40: 142-163.

Herzer, D. (2010). How does foreign direct investment affect developing countries' growth?, IAI Discussion Papers, No. 207, Georg-AugustUniversität Göttingen, Ibero-America Institute for Economic Research (IAI), Göttingen.

Javorcik, S. B. (2004). Does foreign direct investment increase the productivity of domestic firms? In search of spillovers through backward linkages. American Economic Review, Vol. 94 No. 3, pp. 605-627.

Katircioglu, S., Katircioğlu, S., \& Altinay, M. (2017). Interactions between tourism and financial sector development: evidence from Turkey. The Service Industries Journal, 38(9-10), 519-542. doi:10.1080/02642069.2017.1406479

Kauffman, D., Kraay, A. \& Mastruzzi, M. (2009). Governance matters VIII: aggregate and individual governance indicators for 1996-2008. Policy Research Working Paper No. 4978, The World Bank, Washington, DC

Kumar, R. R. (2014). Exploring the role of technology, tourism and financial development: An empirical study of Vietnam. Quality and Quantity, 48(5), 2881-289.

Kumar, R. R., \& Kumar, R. (2013). Exploring the developments in urbanization, aid dependency, sectorial shifts and services sector expansion in Fiji: A modern growth perspective. Global Business and Economics Review, 15, 371-395.

Kumar, R. R., Loganathan, N., Patel, A., \& Kumar, R. D. (2015). Nexus between tourism earnings and economic growth: A study of Malaysia. Quality and Quantity, 49(3), 1101-1120.

Kutan, A. M., Samargandi, N., \& Sohag, K. (2017). Does Institutional Quality Matter for Financial Development and Growth? Further Evidence from MENA Countries. Australian Economic Papers, 56(3), 228-248. doi:10.1111/1467-8454.12097

Lee, C. C., \& Chang, C. P. (2008). Tourism development and economic growth: A closer look at panels. Tourism Management, 29, 180-192.

Li, Q., \& Resnick, A. (2003), Reversal fortunes: democratic institutions and foreign direct investment inflows to developing countries. International Organization, Vol. 57 No. 1, pp. 175-211.

Lipsey, R. E. (2002). Home and host country effects of FDI. NBER Working Paper No. 9293, NBER, Cambridge.

Nguyen, C. P., Su, T. D. \& Nguyen, T. V. H. (2018). Institutional Quality and Economic Growth: The Case of Emerging Economies. Theoretical 
Economics Letters, 8, 1943-1956. https://doi.org/10.4236/tel.2018. 811127

Ohlan, R. (2017). The relationship between tourism, financial development and economic growth in India. Future Business Journal, 3(1), 9-22. doi:10.1016/j.fbj.2017.01.003

Owusu-Nantwi, V. (2019). Foreign direct investment and institutional quality: empirical evidence from South America. Journal of Economic and Administrative Sciences, Emerald Group Publishing, vol. 35(2), pages 6678, June.

Payne, J. E., \& Mervar, A. (2010). The tourism growth nexus in Croatia. Tourism Economics, 16(4), 1089-1094.

Pesaran, M. H., Shin, Y., \& Smith, R. P. (1999). Pooled Mean Group Estimation of Dynamic Heterogeneous Panels. Journal of the American Statistical Association, 94(446), 621. doi:10.2307/2670182

Sabir, S., Rafique, A., \& Abbas, K. (2019). Institutions and FDI: evidence from developed and developing countries. Financial Innovation, 5, 8. https://doi.org/10.1186/s40854-019-0123-

Seetanah, B., \& Fauzel, S. (2019). Investigating the impact of climate change on the tourism sector: evidence from a sample of island economies. Tourism Review, Vol. 74 No. 2, pp. 194-203

Shahbaz, M., Kuma, R. R., Ivanov, S., \& Loganathan, N. (2016). The nexus between tourism demand and output per capita, with the relative importance of trade openness and financial development: A study of Malaysia. Tourism Economics, 1-19, http://dx.doi.org/10.5367/te.2015. 0505

Song, H., \& Lin, S. (2010). Impacts of the financial and economic crisis on tourism in Asia. Journal of Travel Research, 49(1), 16-30

Song, H., \& Lin, S. (2010). Impacts of the financial and economic crisis on tourism in Asia. Journal of Travel Research, 49(1), 16-30.

Song, H., \& Lin, S. (2010). Impacts of the financial and economic crisis on tourism in Asia. Journal of Travel Research, 49(1), 16-30.

Wei, S. J. (2000). How taxing is corruption on international investors? The Review of Economics and Statistics, Vol. 82 No. 1, pp. 1-11. 